\title{
Thermal oxidation of carbon monoxide in air using various self-prepared catalysts
}

\author{
Nguyen Thi Bich Thao, Nguyen Nhat Huy*
}

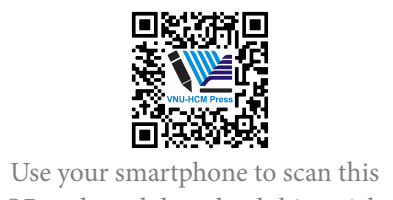

QR code and download this article

\begin{abstract}
Carbon monoxide (CO) is a very toxic pollutant emitted from wood fired boiler, which is widely used in small and medium enterprises in Vietnam. The treatment of $\mathrm{CO}$ containing flue gas faces many difficulties due to the inert property of $\mathrm{CO}$ that cannot be removed by traditional adsorption and absorption methods and one of the effective $\mathrm{CO}$ treatments is catalytic oxidation. Therefore, we aimed to prepare various catalysts on different carriers for treatment of $\mathrm{CO}$ in flue gas, including $\gamma$ $\mathrm{Al}_{2} \mathrm{O}_{3}$-based metal oxides $\left(\mathrm{CO}_{3} \mathrm{O}_{4} / \mathrm{Al}_{2} \mathrm{O}_{3}, \mathrm{Cr}_{2} \mathrm{O}_{3} / \mathrm{Al}_{2} \mathrm{O}_{3}\right.$, and $\left.\mathrm{CuO} / \mathrm{Al}_{2} \mathrm{O}_{3}\right), \mathrm{CuO}-\mathrm{MnOx} / \mathrm{OMS}-2$, and $\mathrm{CuO}-\mathrm{MnOx} /$ zeolite. The $\mathrm{CO}$ removal tests were conducted in a continuous fixed bed reactor in laboratory scale with temperature range of $50-550^{\circ} \mathrm{C}$. The characteristics of catalytic materials were then determined by various methods such as Brunauer-Emmett-Teller measurement, $\mathrm{X}$-ray diffraction, energy-dispersive X-ray spectroscopy, Fourier transform infrared spectroscopy, scanning electron microscopy, and thermogravimetric analysis. Results showed that CuO-MnOx/OMS-2 was the best catalyst with high removal efficiency of $98.41 \%$ at reactor temperature of $250^{\circ} \mathrm{C}$ while gas outlet temperature of $<50^{\circ} \mathrm{C}$, proving the suitability of this material for practical treatment of $\mathrm{CO}$ in flue gas. The reaction follows Mars-Van-Krevelen mechanism with the presence of $\mathrm{Cu}^{2+}-\mathrm{O}^{2-}-\mathrm{Mn}^{4+}$ $\leftrightarrow \mathrm{Cu}^{+}-\square-\mathrm{Mn}^{3+}+\mathrm{O}_{2}$ redox in the structure of the material. Moreover, the effect of environmental factors such as flow rate, inlet $\mathrm{CO}$ concentration, and catalysts amount on the CO removal efficiency were investigated and noted for designing and operation purposes. Concentration of outlet CO met well QCVN 19: 2009/BTNMT - National technical regulation on industrial emissions for dust and inorganic substances. Therefore, $\mathrm{CuO}-\mathrm{MnOx} / \mathrm{OMS}-2$ catalyst material could be a potential catalyst for treatment of $\mathrm{CO}$ in flue gas of boiler.
\end{abstract}

Key words: carbon monoxide, oxidation, catalyst, air pollution control
Ho Chi Minh City University of Technology, VNU-HCM

\section{Correspondence}

Nguyen Nhat Huy, Ho Chi Minh City University of Technology, VNU-HCM

Email: nnhuy@hcmut.edu.vn

History

- Received: 07-3-2019

- Accepted: 14-6-2019

- Published: 31-12-2019

DOI : 10.32508/stdjet.v2iSI2.469

\section{Check for updates}

\section{Copyright}

(c) VNU-HCM Press. This is an openaccess article distributed under the terms of the Creative Commons Attribution 4.0 International license.

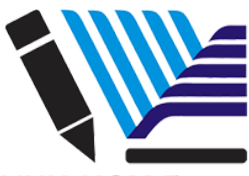

\section{INTRODUCTION}

Every year, millions of tons of carbon monoxide (CO) emitted into the environment cause serious consequences for human health ${ }^{1}$. In addition to natural emission sources, carbon monoxide (CO) is also generated by incomplete combustion of carboncontaining substances in wood-fired boilers, waste incinerators and other processes. In Vietnam, many small and medium enterprises are using wood boilers as main heat energy source for their production process. Due to the limited budget and low technology, most of the wood boilers are cheap and inefficient and the incomplete combustion results in high concentration of $\mathrm{CO}$ in the flue gas. In order to meet the more and more strictly environmental regulations for emissions, several methods have been studied and some have been commercialized ${ }^{2}$. One of the most effective ways to treat $\mathrm{CO}$ is oxidation in the presence of a catalyst ${ }^{3}$.

Noble metal containing catalysts such as $\mathrm{Au} / \mathrm{TiO}_{2}$, $\mathrm{Au} / \mathrm{ZrO}_{2}$ and $\mathrm{Pt} / \mathrm{SnO}_{2}$ have been used for low temperature $\mathrm{CO}$ oxidation. However, due to the high cost and limited availability of noble and precious metals, the research group paid more attention to the goal of preparation and testing using popular metal catalysts for this application. In particular, $\mathrm{Cu}$ is widely mentioned because of its high activity for CO conversion at low temperatures ${ }^{4}$. Studies show that the catalytic activity of $\mathrm{CuO}$ depends on the oxidation state of $\mathrm{Cu}$ and especially on the nature of the carrier. A number of common carriers have been studied including $\mathrm{CeO}_{2}, \mathrm{Al}_{2} \mathrm{O}_{3}$, zeolite, and OMS-2. The increase in catalytic activity of $\mathrm{Cu}$ when carried on reducing oxides like $\mathrm{CeO}_{2}$ is explained by the synergistic effect due to the good dispersion of $\mathrm{CuO}$ on $\mathrm{CeO}_{2}$ lead to the possibility of reduction at lower temperatures than $\mathrm{CuO}^{5}$. Among new catalysts, octahedral molecular sieves (OMS) on the basis of manganese oxide which has a wide range of reactions, especially for oxidation reactions. Currently, there have not been many studies focusing on the treatment of $\mathrm{CO}$ in the waste biomass boiler (which has a temperature of about 250 ${ }^{\circ} \mathrm{C}$ ) using catalysts that do not contain nobles metals. 
Therefore, in this study, the research group focused on the preparation of different catalytic materials and investigated the activity of these catalysts to apply for oxidation of $\mathrm{CO}$ in air at different temperatures. The effect of environmental factor such as inlet $\mathrm{CO}$ concentration, gas flowrate, and catalyst amount were also investigated.

\section{MATERIALS AND METHODS}

\section{Material synthesis and characterization}

All chemical used are analytical-grade from China and Vietnam. Figures of all materials are displayed in Figure 1. Manganese oxide octahedral molecular sieves (OMS-2) were synthesized by a hydrothermal method ${ }^{6}$ as follows: $11.33 \mathrm{~g} \mathrm{MnSO}_{4} \cdot \mathrm{H}_{2} \mathrm{O}$ dissolved in $120 \mathrm{~mL}$ of deionized water was added to a solution of $7.57 \mathrm{~g} \mathrm{KMnO}_{4}$ in $38 \mathrm{~mL}$ of deionized water and $4 \mathrm{~mL}$ of concentrated $\mathrm{HNO}_{3}$. The obtained mixture was transferred into a $165 \mathrm{~mL}$ Teflon-lined stainless steel autoclave and heated at $160{ }^{\circ} \mathrm{C}$ for $24 \mathrm{~h}$. The product was then filtered, washed with deionized water and dried at $105^{\circ} \mathrm{C}$ for $12 \mathrm{~h}$. The material was obtained after calcination at $400{ }^{\circ} \mathrm{C}$ for $4 \mathrm{~h}$ and denoted as OMS-2.

Catalyst of $\mathrm{CuO}-\mathrm{MnO}_{x} / \mathrm{OMS}-2$ with 15 wt.\% of CuO$\mathrm{MnOx}$ (Cu:Mn molar ratio of 6:4) was prepared by impregnation method. Calculated amounts of $\mathrm{Cu}\left(\mathrm{NO}_{3}\right)_{2} \cdot 3 \mathrm{H}_{2} \mathrm{O}$ and $\mathrm{MnSO}_{4} \cdot \mathrm{H}_{2} \mathrm{O}$ were dissolved in deionized water and impregnated with OMS -2 . The mixture was mixing and sonicated for $30 \mathrm{~min}$, followed by stirring and heated at $80^{\circ} \mathrm{C}$ for $15 \mathrm{~min}$. After that, the material was dried at $105^{\circ} \mathrm{C}$ for $12 \mathrm{~h}$ and finally ground and calcined at $400^{\circ} \mathrm{C}$ for $4 \mathrm{~h}$.

$\mathrm{CuO} / \mathrm{Al}_{2} \mathrm{O}_{3}$ catalysts were prepared by impregnation method with copper nitrate aqueous solution of the desired concentrations ${ }^{7}$. At first, $2.82 \mathrm{~g}$ of $\mathrm{Zn}\left(\mathrm{NO}_{3}\right)_{2} \cdot 6 \mathrm{H}_{2} \mathrm{O}$ and $11.29 \mathrm{~g}$ of $\mathrm{Al}(\mathrm{OH})_{3}$ were dissolved in distilled water. The mixture was then dried at $105^{\circ} \mathrm{C}$ and calcination in air at $500{ }^{\circ} \mathrm{C}$ for $6 \mathrm{~h}$. After that, $\mathrm{CuO}$ was impregnated by adding of $5.584 \mathrm{~g}$ $\mathrm{Cu}\left(\mathrm{NO}_{3}\right)_{2}$ into the mixture, followed by drying at 105 ${ }^{\circ} \mathrm{C}$ and calcination in air at $600{ }^{\circ} \mathrm{C}$ for $6 \mathrm{~h}$.

$\mathrm{Cr}_{2} \mathrm{O}_{3} / \mathrm{Al}_{2} \mathrm{O}_{3}$ sample containing 15.7 wt. $\%$ of $\mathrm{Cr}_{2} \mathrm{O}_{3}$ were prepared by mixing a known mass of finely powdered $\mathrm{Al}(\mathrm{OH})_{3}$ with a calculated amount of $\mathrm{CrO}_{3}$ solid, followed by drying at $120^{\circ} \mathrm{C}$ and calcination in air at $800{ }^{\circ} \mathrm{C}$ for $6 \mathrm{~h}^{8}$.

The materials were characterized by BrunauerEmmett-Teller (BET, Porous Materials, BET-202A), scanning electron microscopy (SEM) with energydispersive X-ray spectroscopy (EDS) (JEOL JSMIT200), X-ray diffraction (XRD, D2 Phaser, Bruker),

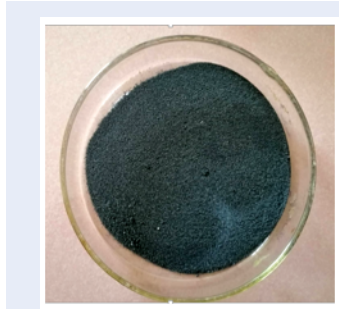

$\mathrm{Co}_{3} \mathrm{O}_{4} / \mathrm{Al}_{2} \mathrm{O}_{3}$

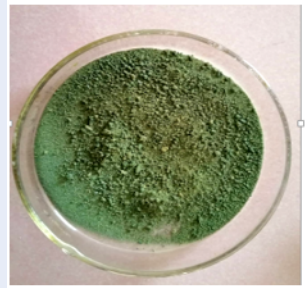

$\mathrm{Cr}_{2} \mathrm{O}_{3} / \mathrm{Al}_{2} \mathrm{O}_{3}$

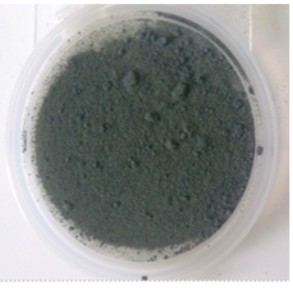

$\mathrm{CuO} / \mathrm{Al}_{2} \mathrm{O}_{3}$

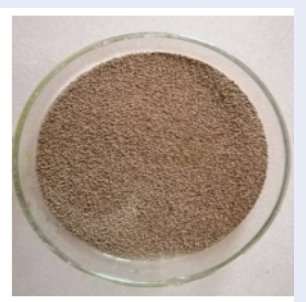

$\mathrm{CuO} / \mathrm{OMS}-2$

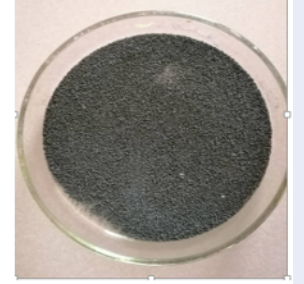

CuO-MnOx/OMS-2

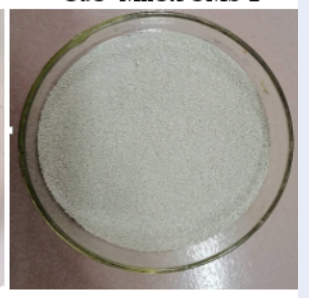

CuO-MnOx/zeolite
Figure 1: Pictures of catalysts used in the study.

Fourier transform infrared spectroscopy (FTIR, Bruker-FTIR), and thermogravimetric analysis (TGA, TGA Q500 machine).

\section{Catalytic activity test}

The micro-flow reaction system (Figure 2) consists of 3 parts: gas supply system, reaction system, and analysis system. Gas flow is supplied from clean gas pump and gas cylinder containing 5\% CO balanced in $\mathrm{N}_{2}$. The $\mathrm{CO}$ gas is then diluted with clean air for reaching desire concentration of around $2000 \mathrm{ppm}$ before feeding into the reaction. All gas flowrates were controlled by mass flow controller (MFC) with typical total flowrate was kept stably at around $1 \mathrm{~L} / \mathrm{min}$. Catalysts with amount of 0.4 or $1 \mathrm{~g}$ and particle size through a $20-40$ mesh sieve was placed inside the reactor to form a packed column inside the reaction tube. The catalyst was pre-activated in air stream at $250{ }^{\circ} \mathrm{C}$ for $30 \mathrm{~min}$ every first use of a new catalyst. All the experiments were conducted three times and the average values are presented in the manuscript.

The concentration of CO in the inlet and outlet were continuously monitored by using a portable emissions analyzer (Testo $350 \mathrm{XL}$, Germany). The efficiency of CO treatment was then calculated as Equa- 
tion (1) and used as a criteria for evaluation the ability of the catalysts at different reaction temperatures.

$$
H=\frac{C_{\text {in }}-C_{\text {out }}}{C_{\text {in }}} \times 100 \%
$$

Where $\mathrm{H}$ is the removal efficiency (\%). $\mathrm{C}_{\text {in }}$ and $\mathrm{C}_{\text {out }}$ are the inlet and outlet $\mathrm{CO}$ concentration (ppm), respectively.

In this study, different types of catalyst (i.e., $\mathrm{Co}_{3} \mathrm{O}_{4}$, $\mathrm{CuO}, \mathrm{Cr}_{2} \mathrm{O}_{3}$, and $\mathrm{CuO}-\mathrm{MnOx}$ ) and carrier (i.e., $\mathrm{Al}_{2} \mathrm{O}_{3}$, OMS-2, and zeolite) was tested in order to find the best material for $\mathrm{CO}$ oxidation. Moreover, environmental factors such as temperature $\left(50-500{ }^{\circ} \mathrm{C}\right)$, flow rate $(0.52-1.3 \mathrm{~L} / \mathrm{min})$, CO concentration (500 $4500 \mathrm{ppm})$, and catalysts amount $(0.25-1.25 \mathrm{~g}$ ) on the CO removal efficiency were investigated.

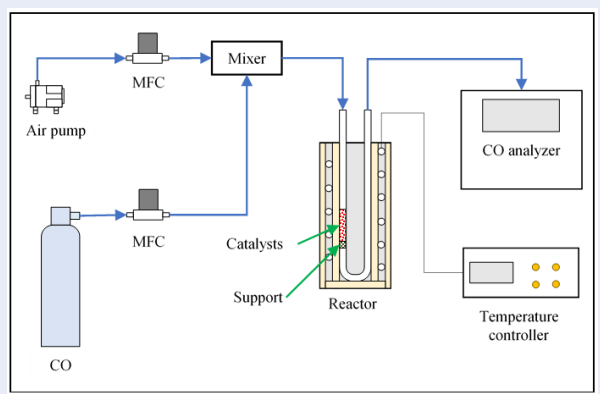

Figure 2: Experimental set-up for catalytic oxidation of CO.

\section{RESULTS AND DISCUSSION}

\section{Material characterization}

The BET surface area of catalysts are summarized in Table 1. It can be seen that surface area of OMS-2 support is $62.50 \mathrm{~m}^{2} / \mathrm{g}$ and that of $\mathrm{CuO}-\mathrm{MnOx} / \mathrm{OMS}$ 2 is $52.76 \mathrm{~m}^{2} / \mathrm{g}$, which was slightly lower than that of OMS-2 support. The decrease in surface area of OMS-2 material after doping with copper oxidemanganese oxide mixture somehow demonstrates the dispersion of metal oxides on the surface of the support. SEM images of OMS-2 materials are presented in Figure 3. Both pure and doped OMS-2 materials exhibits nanowires morphology with diameters of about $13 \mathrm{~nm}$ and lengths of several $\mu \mathrm{m}$. Figure 4 shows the XRD patterns of OMS- 2 catalysts. The diffraction peaks at $2 \theta$ of $12.6^{\circ}, 17.9^{\circ}, 28.7^{\circ}, 37.5^{\circ}$, $41.9^{\circ}, 49.9^{\circ}$, and $60.1^{\circ}$ are attributed to the crystalline phase of cryptomelane $\left(\mathrm{KMn}_{8} \mathrm{O}_{16}\right)$, indicating that the nanowires OMS-2 materials has a cryptomelanetype structure ${ }^{9}$.
Table 1: BET surface are of catalysts

\begin{tabular}{ll}
\hline Catalyst & BET surface area $\left(\mathbf{m}^{2} / \mathbf{g}\right)$ \\
OMS-2 & 62.50 \\
$\mathrm{CuO}-\mathrm{MnO}_{x} / \mathrm{OMS}-2$ & 52.76 \\
\hline
\end{tabular}

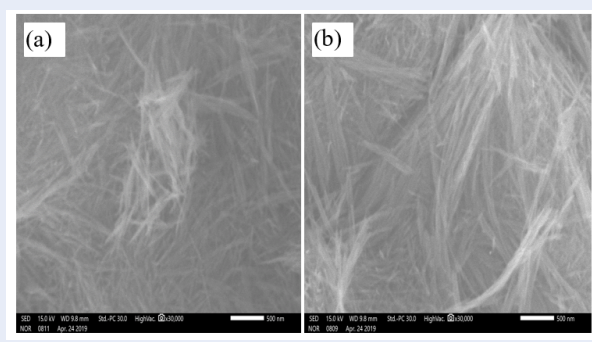

Figure 3: SEM images of (a) OMS-2, (b) CuOMnOx/OMS-2.

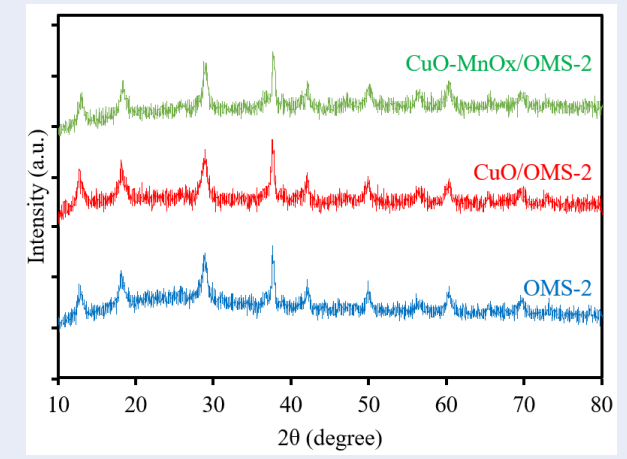

Figure 4: XRD patterns of OMS-2, CuO/OMS-2, and $\mathrm{CuO}-\mathrm{MnO}_{x} / \mathrm{OMS}-2$ catalysts.

EDS result of $\mathrm{CuO}-\mathrm{MnOx} / \mathrm{OMS}-2$ is presented in Figure 5 while those of all OMS-2 materials are summarized in Table 2. The major components of the OMS2 materials were oxygen and manganese while copper was detected in doped samples. Surface chemical property of the material has strong effect on the catalytic activity of the material ${ }^{10}$. FTIR results in Figure 6 present an octahedral structure of OMS-2 with wave number in range of $800-400 \mathrm{~cm}^{-111}$. The peak at $470 \mathrm{~cm}^{-1}$ is attributed to $\mathrm{Mn}^{4+}$ in octahedral structure while peak at $475 \mathrm{~cm}^{-1}$ is assigned to the oxygen transfer ${ }^{12}$. The oscillation of $\mathrm{Cu}-\mathrm{O}$ were observed at peaks of 430,439 , and $461 \mathrm{~cm}^{-1}$ for $\mathrm{CuO} / O M S$ 2 sample ${ }^{13,14}$. These peaks were also found in FTIR spectra of $\mathrm{CuO}-\mathrm{MnOx} / \mathrm{OMS}-2$ but with lower intensity, indicating lower amount of copper oxide on the OMS-2 surface. In addition, the present of water was also observed at peaks of 3430 and $1626 \mathrm{~cm}^{-115}$. 
Thermogravimetric analysis of OMS-2 materials were also done, and the results of $\mathrm{CuO} \mathrm{CuO}-\mathrm{MnOx} / \mathrm{OMS}$ -

2 is presented in Figure 7. The weight loss of around $2 \%$ with temperature $<400{ }^{\circ} \mathrm{C}$ could be due to the water release while the loss at temperature range of 400 - $700{ }^{\circ} \mathrm{C}$ could be the structural decomposition of the materials at high temperature.
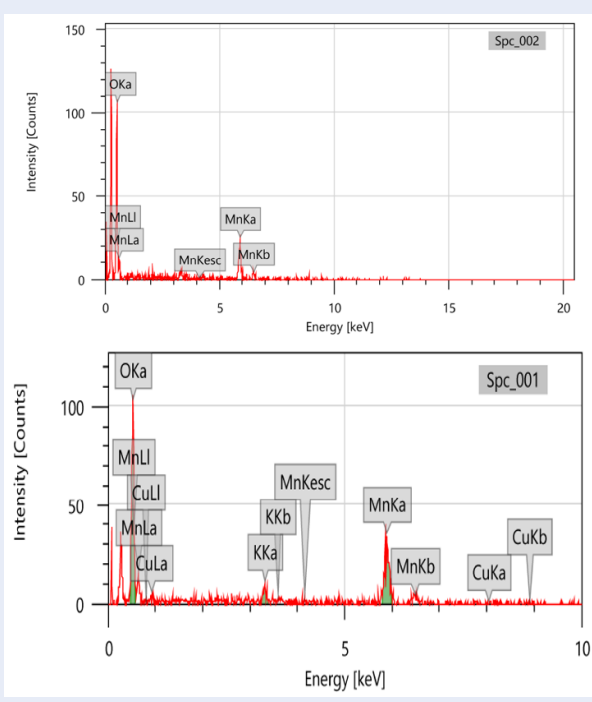

Figure 5: EDS results of OMS-2 and CuO$\mathrm{MnO}_{x} / \mathrm{OMS}-2$.

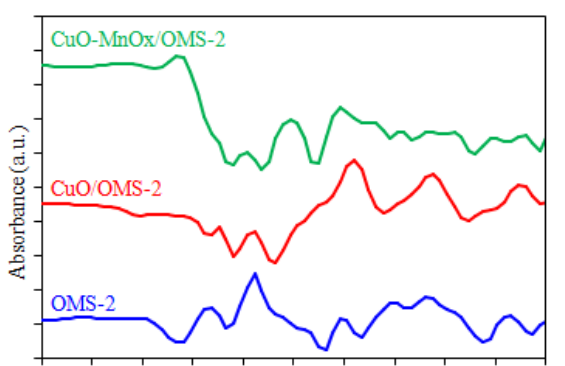

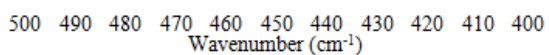

Figure 6: FTIR of OMS-2, CuO/OMS-2 and CuOMnOx/OMS-2 catalysts.

Activity of catalysts based on $\mathrm{Al}_{2} \mathrm{O}_{3}$ carrier Experimental results with $\mathrm{Co}_{3} \mathrm{O}_{4} / \mathrm{Al}_{2} \mathrm{O}_{3}$, $\mathrm{CuO} / \mathrm{Al}_{2} \mathrm{O}_{3}$, and $\mathrm{Cr}_{2} \mathrm{O}_{3} / \mathrm{Al}_{2} \mathrm{O}_{3}$ catalysts in Figure 8 show that $\mathrm{CO}$ conversion increases with reaction temperature. For $\mathrm{Co}_{3} \mathrm{O}_{4} / \mathrm{Al}_{2} \mathrm{O}_{3}$ and $\mathrm{CuO} / \mathrm{Al}_{2} \mathrm{O}_{3}$, the highest conversion efficiency was achieved at $500{ }^{\circ} \mathrm{C}$, reached $99.60 \%$ for $\mathrm{Co}_{3} \mathrm{O}_{4} / \mathrm{Al}_{2} \mathrm{O}_{3}$ and 93.94

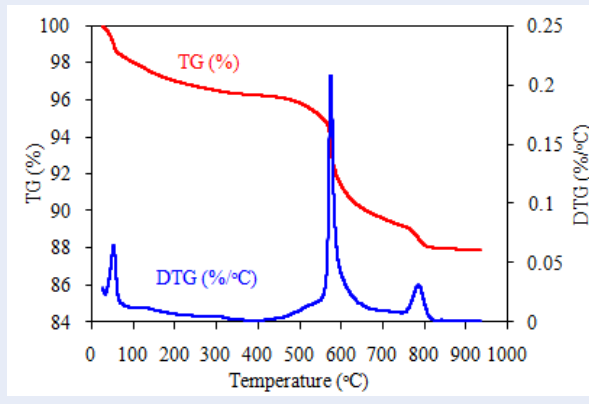

Figure 7: TGA result of CuO-MnOx/OMS-2 catalysts.

$\%$ for $\mathrm{CuO} / \mathrm{Al}_{2} \mathrm{O}_{3}$. In $\mathrm{t}$ he temperature range of $50-250{ }^{\circ} \mathrm{C}, \mathrm{CO}$ gas is inert and not converted to $\mathrm{CO}_{2}$. $\mathrm{CO}$ conversion started from $300{ }^{\circ} \mathrm{C}$ and increased at higher temperatures. For $\mathrm{Cr}_{2} \mathrm{O}_{3} / \mathrm{Al}_{2} \mathrm{O}_{3}$ material as catalyst, $\mathrm{CO}$ conversion did not occur or was very limited even when increasing the reaction temperature. The highest performance at $400{ }^{\circ} \mathrm{C}$ temperature was only $11.62 \%$. This proves that the catalytic activity of $\mathrm{Cr}_{2} \mathrm{O}_{3} / \mathrm{Al}_{2} \mathrm{O}_{3}$ is very low and this material is not suitable for $\mathrm{CO}$ conversion in the exhaust gas.

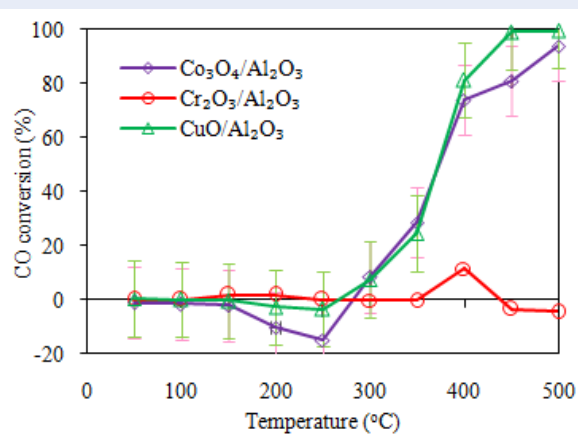

Figure 8: $\mathrm{CO}$ conversion efficiency of $\mathrm{Co}_{3} \mathrm{O}_{4}$, $\mathrm{Cr}_{2} \mathrm{O}_{3}$, and $\mathrm{CuO}$ catalysts based on $\mathrm{Al}_{2} \mathrm{O}_{3}$ carrier at different temperatures.

Activity of catalysts based on OMS-2 and zeolite carrier

The ability of CuO/OMS-2, CuO-MnOx/OMS-2, and $\mathrm{CuO}-\mathrm{MnOx} /$ zeolite catalysts for $\mathrm{CO}$ conversion are shown in Figure 9. Similar to $\mathrm{Al}_{2} \mathrm{O}_{3}$-based catalysts, $\mathrm{CO}$ conversion efficiencies by these catalysts was ineffective at $50{ }^{\circ} \mathrm{C}$ and increased with the reaction temperature. For $\mathrm{CuO} / \mathrm{OMS}-2$, the highest removal efficiency at $500{ }^{\circ} \mathrm{C}$ and reached $73.15 \%$. At the temperature range of $50-250{ }^{\circ} \mathrm{C}$, low $\mathrm{CO}$ conversion of 


\begin{tabular}{llll}
\multicolumn{4}{l}{ Table 2: Atomic percentage of element } \\
\hline Materials & $\mathbf{O}$ & $\mathbf{M n}$ & $\mathbf{C u}$ \\
$\mathrm{OMS}-2$ & 40.11 & 59.89 & - \\
$\mathrm{CuO} / \mathrm{OMS}-2$ & $60.40 \pm 3.18$ & $36.24 \pm 2.97$ & $3.36 \pm 1.50$ \\
$\mathrm{CuO}-\mathrm{MnO}_{x} / \mathrm{OMS}-2$ & $64.45 \pm 2.66$ & $30.97 \pm 2.14$ & $1.13 \pm 0.70$ \\
\hline
\end{tabular}

$6.44 \%$ was observed. And the conversion starts to be effective when the temperature was higher than 250 ${ }^{\circ} \mathrm{C}$.

For $\mathrm{CuO}-\mathrm{MnOx} / \mathrm{OMS}-2$ material, $\mathrm{CO}$ conversion increases with both the reaction temperature and the amount of catalyst. When more catalyst are used, CO conversion efficiency will be higher and more stable over time. With $0.4 \mathrm{~g}$ of material, the highest efficiency was $98.66 \%$ (at $600{ }^{\circ} \mathrm{C}$ ). With $1 \mathrm{~g}$ of catalyst, the highest conversion efficiency was $99.96 \%$ only at $500{ }^{\circ} \mathrm{C}$. Moreover, it is also observed from Figure 9 that, the conversion efficiency increases very fast at low temperatures from $50-250{ }^{\circ} \mathrm{C}$ but the efficiency starts to slow down when temperature over $250{ }^{\circ} \mathrm{C}$ and become more stable. The results also proved that $\mathrm{CuO}-\mathrm{MnOx} / \mathrm{OMS}-2$ materials was effective for $\mathrm{CO}$ removal and stable over time. On the octahedral molecular catalytic surface (OMS-2), the Mn-O bonds are relative weak, so that flexible surface oxygen atoms are able to participate in the reaction and restore to its original state when oxygen supply from gas flow is available. Compared to some other catalysts (e.g., Pt-catalytic conversion system reaches $50 \%$ at $290{ }^{\circ} \mathrm{C}^{16}$ ), $\mathrm{CuO}-\mathrm{MnOx} / \mathrm{OMS}-2$ has higher activity due to the combination of $\mathrm{Mn}$ and $\mathrm{Cu}$ can produce Hopcalite $\mathrm{CuMn}_{2} \mathrm{O}_{4}$ with high oxidizing activity for CO removal.

For CuO-MnOx/zeolite catalyst, the highest efficiency was at a temperature of $500{ }^{\circ} \mathrm{C}$ and reached $96.92 \%$. In the temperature range of $50-350{ }^{\circ} \mathrm{C}$, $\mathrm{CO}$ conversion did not occurred. The conversion of $\mathrm{CO}$ starts to be effective at $400{ }^{\circ} \mathrm{C}$ but from this temperature or above, the ability of $\mathrm{CO}$ conversion increases slowly and stably over time. In the contrary, the treatment efficiency increased very rapidly from 0 to $94.63 \%$ in temperature range of $350-450{ }^{\circ} \mathrm{C}$. It is obvious that $\mathrm{CuO}-\mathrm{MnOx} / \mathrm{OMS}-2$ had the highest removal efficiency of $98.41 \%$ at low temperature of 250 ${ }^{\circ} \mathrm{C}$. Therefore, it was chosen as catalyst for further experiments.

In order to clarify the effect of $\mathrm{CuO}$ and $\mathrm{MnOx}$ on the OMS-2 support, the comparison experiments were conducted using OMS-2, CuO/OMS-2, and $\mathrm{CuO}-$ $\mathrm{MnO}_{x} / \mathrm{OMS}-2$ materials. As seen in Figure 10, $\mathrm{CO}$ removal increases with the increase of temperature.

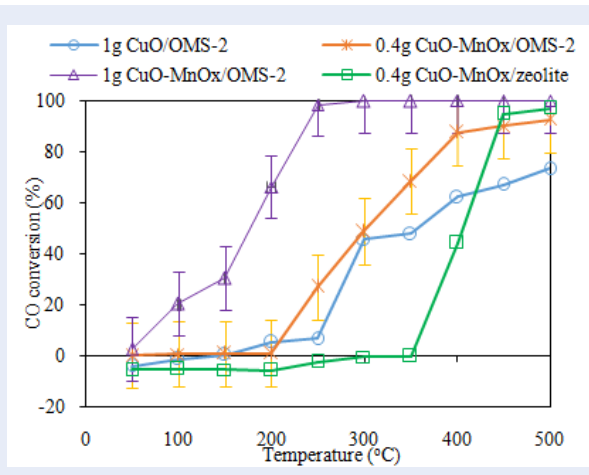

Figure 9: CO conversion efficiency of OMS-2 and zeolite based catalysts at different temperatures.

For OMS-2, CO gas was relative inert at low temperature of $50-100{ }^{\circ} \mathrm{C}$ while it started to be oxidized to $\mathrm{CO}_{2}$ at temperature of $150{ }^{\circ} \mathrm{C}$. This can be explained by the low activity of OMS- 2 support without the presence of copper, which only reached the removal efficiency of $31.89 \%$ at $200{ }^{\circ} \mathrm{C}$. Compared to OMS-2, CuO/OMS-2 and CuO-MnOx/OMS-2 had higher catalytic activity due to the doping of copper with $\mathrm{Cu}^{2+}-\mathrm{O}^{2-}-\mathrm{Mn}^{4+}$ bonds on the support surface. At catalyst surface, $\mathrm{CO}$ combines with oxygen in $\mathrm{Cu}^{2+}-\mathrm{O}^{2-}-\mathrm{Mn}^{4+}$ to form $\mathrm{CO}_{2}$ and leaves an oxygen vacancy $\left(\mathrm{Cu}^{+}-\mathrm{o}-\mathrm{Mn}^{3+}\right)$. These oxygen vacancies were then instantly occupied by free oxygen in the air thus act as active sites for reaction of $\mathrm{CO}^{17}$. Accordingly, the reaction of $\mathrm{CO}$ is continuously occurred on the surface of the catalyst due to the presence of $\mathrm{Cu}^{2+}{ }_{-} \mathrm{O}^{2-}-\mathrm{Mn}^{4+} \leftrightarrow \mathrm{Cu}^{+}-\mathrm{O}-\mathrm{Mn}^{3+}+\mathrm{O}_{2}$ redox. The oxidation of $\mathrm{CO}$ to form $\mathrm{CO}_{2}$ follows MarsVan-Krevelen mechanism ${ }^{6}$.

Figure 11 demonstrates the effect of calcination temperature on the activity of $\mathrm{CuO}-\mathrm{MnO}_{x} / \mathrm{OMS}-2$ material for $\mathrm{CO}$ oxidation. One can see that the catalytic activity gradually decreases with the increase of calcination temperature from 400 to $600{ }^{\circ} \mathrm{C}$ but significantly decreases with further increase of temperature to 700 and $800{ }^{\circ} \mathrm{C}$. Thus, the activity of $\mathrm{CuO}$ $\mathrm{MnO}_{x} / \mathrm{OMS}-2$ depends on calcination temperature 


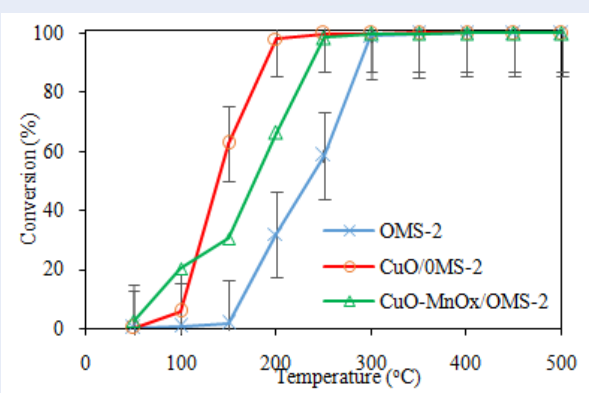

Figure 10: CO conversion efficiency of OMS-2, CuO/OMS-2 and CuO-MnOx/OMS-2 catalysts at different temperatures.

and the temperature of $400{ }^{\circ} \mathrm{C}$ is suitable for posttreatment of the material in terms of material structure, removal efficiency, and energy consumption.

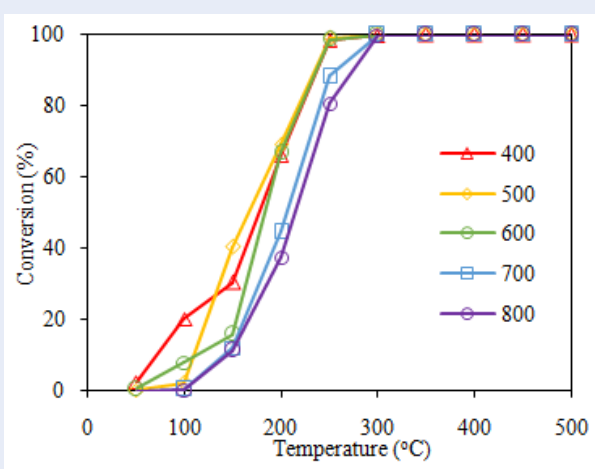

Figure 11: Effect of calcination tem perature on the a ctivity of $\mathrm{CuO}-\mathrm{MnO}_{x} / \mathrm{OMS}-2$ catalysts for $\mathrm{CO}$ oxidation.

\section{Effect of other environmental factors}

Figures 12, 13, 14 and 15 illustrates the effect of operational condition on the $\mathrm{CO}$ removal using $\mathrm{CuO}$ $\mathrm{MnOx} / \mathrm{OMS}-2$ material. In Figure 12, the $\mathrm{CO}$ removal efficiency increases with the increase of $\mathrm{CO}$ concentration from 526 to $2300 \mathrm{ppm}$, where it reaches maximum efficiency of $98.41 \%$. This could be explained by the gas bulk mass transfer of CO increase in this low inlet concentration range. However, further increase of CO concentration slightly decreases its removal efficiency, possibly due to the limitation of catalyst surface active sites for $\mathrm{CO}$ adsorption and reaction. This should be noted when designing a catalytic system for practical application where CO concentration in flue gas fluctuates from 200 to $5000 \mathrm{ppm}$. The lower inlet concentration of CO could result in lower removal efficiency while the outlet concentration is required to meet emission standard (QCVN 19: 2009/BTNMT).

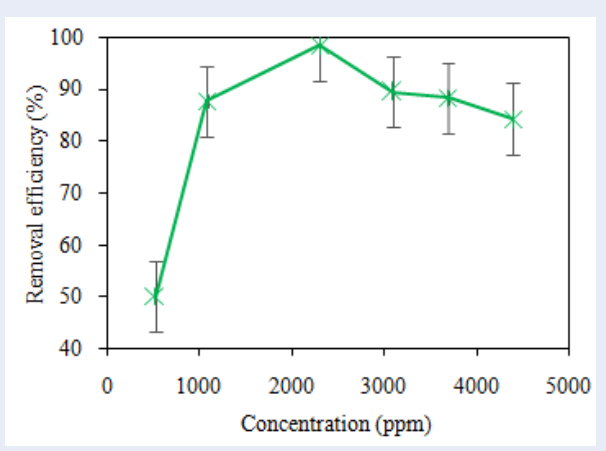

Figure 12: Effect of inlet CO concentration (1 $\mathrm{g}$ CuO-MnOx/OMS-2, $250^{\circ} \mathrm{C}, 1 \mathrm{~L} / \mathrm{min}, \mathrm{n}=3$ ).

In actual small wood boilers, the flowrate of flue gas usually fluctuates due to the variation in steam amount need of the production process. Figure 13 presents the effect of gas flowrate on the removal efficiency of CO. It is obvious that the removal efficiency continuously decreases with the increase of flowrate. The reason is mostly based on the gas retention time, where higher flowrate means shorter retention time for $\mathrm{CO}$ reaction on the catalyst surface. This result also indicates that if a designed catalyst system works well with the highest flue gas flowrate, it could even work better under lower flowrate condition.

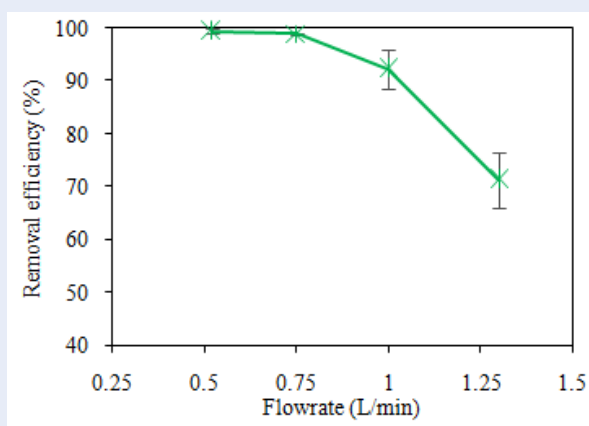

Figure 13: Effect of inlet gas flow rate $(1 \mathrm{~g} \mathrm{CuO-}$ MnOx/OMS-2, 2300 ppm CO, $250^{\circ} \mathrm{C}, \mathrm{n}=3$ ).

In order to clarify the effect of both flowrate and concentration on the removal ability of $\mathrm{CO}$, the constant amount of $\mathrm{CO}$ was maintained while both flowrate and concentration was changed. The result is displayed in Figure 14 for flowrate range of 0.5 to 1.0 $\mathrm{L} / \mathrm{min}$ and CO range of 4132 to $2045 \mathrm{ppm}$. It can be 
observed that the removal efficiency is more dependent on the flowrate than on the concentration in the investigated range. This implies that the gas retention time should be a more important designing parameter than the operational concentration of CO concentration in the practical application.

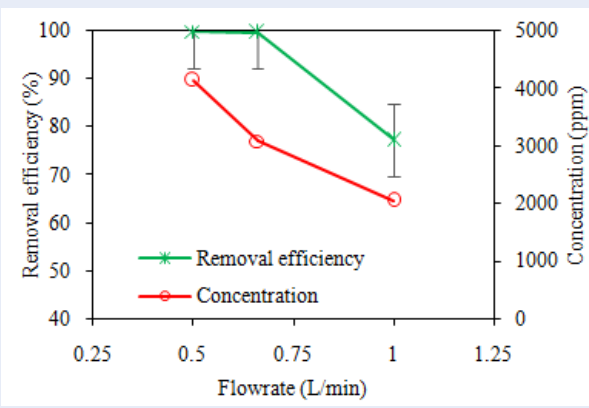

Figure 14: Effect of both inlet gas flow rate and concentration under constant mass flowrate of $\mathrm{CO}\left(1 \mathrm{~g} \mathrm{CuO}-\mathrm{MnOx} / \mathrm{OMS}-2,250^{\circ} \mathrm{C}, \mathrm{n}=3\right.$ ).

The amount of catalyst used in a practical system is important design criteria. Too much catalyst would take more cost and high pressure drop while too less catalyst result in low efficiency. The effect of catalyst amount on CO removal is demonstrated in Figure 15. It is obvious that the efficiency increases from 64.6 to $99.7 \%$ with the catalyst amount from 0.25 to $1.25 \mathrm{~g}$ due to the more active surface available for $\mathrm{CO}$ adsorption and reaction. However, the linear increase of efficiency was not observed for whole investigated range. The amount of $1 \mathrm{~g}$ could be the most suitable with the efficiency of $98.4 \%$ while $1.25 \mathrm{~g}$ is an excess amount with inefficient use by $\mathrm{CO}$ concentration of $2300 \mathrm{ppm}$ and gas flowrate of $1 \mathrm{~L} / \mathrm{min}$.

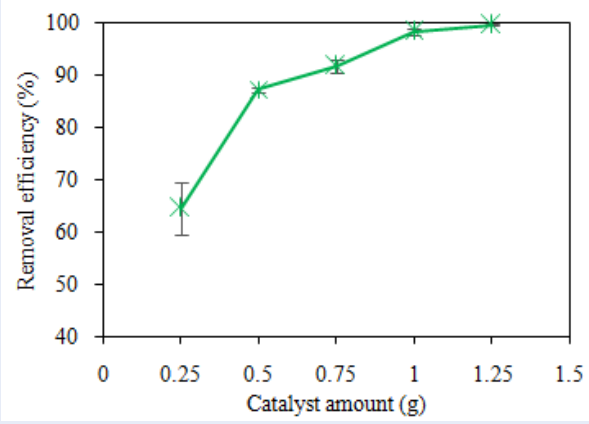

Figure 15: Effect of catalyst amount (CuOMnOx/OMS-2, 2300 ppm CO, $1 \mathrm{~L} / \mathrm{min}, 250{ }^{\circ} \mathrm{C}$, $\mathbf{n}=\mathbf{3}$ ).

\section{CONCLUSION}

Catalysts of $\quad \mathrm{Co}_{3} \mathrm{O}_{4} / \mathrm{Al}_{2} \mathrm{O}_{3}, \quad \mathrm{Cr}_{2} \mathrm{O}_{3} / \mathrm{Al}_{2} \mathrm{O}_{3}$, $\mathrm{CuO} / \mathrm{Al}_{2} \mathrm{O}_{3}, \mathrm{CuO}-\mathrm{MnO} / \mathrm{OMS}-2$, and CuO$\mathrm{MnOx} /$ zeolite were synthesized by impregnation and hydrothermal methods and applied for oxidation of carbon monoxide gas in air. The results show that most catalysts increased activity with the increase of reaction temperature. Among them, CuO-MnOx/OMS-2 catalyst material had the highest efficiency at $250{ }^{\circ} \mathrm{C}$ and stable activity during reaction time. The most suitable operational condition was found to be inlet $\mathrm{CO}$ concentration of $2300 \mathrm{ppm} \mathrm{CO}$, gas flowrate of $1 \mathrm{~L} / \mathrm{min}$, and catalyst amount of $1 \mathrm{~g}$. These result shows a potential use of $\mathrm{CuO}-\mathrm{MnOx} / \mathrm{OMS}-2$ material as an effective catalyst for treatment of $\mathrm{CO}$-containing flue gas in practical application.

\section{ACKNOWLEDGEMENT}

This research is funded by Ho Chi Minh City University of Technology - VNU-HCM under grant number TSĐT-MTTN-2017-23.

\section{ABBREVIATION}

CO: Carbon monoxide Cácbon monoxít

OMS: Octahedral Molecular Sieves Rây phân tử bát diện

OMS-2: $2 \times 2$ type OMS Rây phân tử bát diện có cấu trúc đường ống $2 \times 2$

BET: Brunauer - Emmett - Teller Phương pháp đo diện tích bề mặt riêng

SEM: Scanning Electron Microscope Kính hiển vi điện tử quét

XRD: X-Ray Diffraction Nhiễu xạ tia X

FTIR: Fourier Transform Infrared Quang phổ hông ngoại

TGA: Thermogravimetric Analysis Phân tích nhiệt trọng trường

QCVN: National technical regulation Quy chuẩn Việt Nam

BTNMT: Ministry of Natural Resources and Environment Bộ Tài nguyên và Môi trường

\section{CONFLICT OF INTEREST}

There is no conflict of interest regarding this manuscript.

\section{AUTHOR CONTRIBUTION}

Nguyen Thi Bich Thao do the experiment, collect and process data, and prepare the manuscript Nguyen Nhat Huy outline the research, plan the experiment, check and complete the manuscript 


\section{REFERENCES}

1. Sykes OT, Waker E. The neurotoxicology of carbon monoxide - Historical perspective and review. Cortex. 2016;74:440-448.

2. Li P, Miser DE, Rabiei $S$, et al. The removal of carbon monoxide by iron oxide nanoparticles. Appl Catal B: Environmental. 2003;43:151-162.

3. Thoảng HS, Lộc LC. Chuyển hóa hidrocacbon và cacbon oxit trên các hệ xúc tác kim loại và oxit kim loại. Hà Nội: Nxb. Khoa học tự nhiên và Công nghệ; 2007.

4. Pillai UR, Deevi S. Room temperature oxidation of carbon monoxide over copper oxide catalyst. Appl Catal B. 2006;64:146-153.

5. Mrabet D, Abassi A, Cherizol R, Do TO. One-pot solvothermal synthesis of mixed $\mathrm{Cu}-\mathrm{Ce}-\mathrm{Ox}$ nanocatalysts and their catalytic activity for low temperature CO oxidation. Appl Catal A: General. 2012;p. 447-448. 60-66.

6. Liu XS, et al. Highly active CuO/OMS-2 catalysts for lowtemperature $\mathrm{CO}$ oxidation. Chemical Engineering Journal. 2010;162(1):151-157.

7. El-Shobaky HG, Mokhtar M, El-Shobaky GA. Physicochemical surface and catalytic properties of $\mathrm{CuO}-\mathrm{ZnO} / \mathrm{Al} 2 \mathrm{O} 3$ system. Applied Catalysis A: General. 1999;180(1-2):335-344.

8. El-Shobaky HG, Ghozza AM, El-Shobaky GA, Mohamed GM. Physicochemical surface and catalystic properties of $\mathrm{Cr} 2 \mathrm{O} 3 / \mathrm{Al} 2 \mathrm{O} 3$ system. Colloids and Surfaces A: Physicochemical and Engineering Aspects. 1999;152(3):315-326

9. Sithambaram S, Nyutu EK, Suib SL. OMS-2 catalyzed oxidation of tetralin: A comparative study of microwave and conven- tional heating under open vessel conditions. Applied Catalysis A: General. 2008;348:214-220.

10. Comotti M, Li WC, Spliethoff B, Schth F. Support effect in high activity gold catalysts for $\mathrm{CO}$ oxidation. Journal of the American Chemical Society. 2006;128:917-924.

11. Garces L, Hincapie B, Makwana V, Laubernds K, Sacco A, Suib $S$. Effect of using polyvinyl alcohol and polyvinyl pyrrolidone in the synthesis of octahedral molecular sieves. Microporous and mesoporous materials. 2003;63:11-20.

12. Abulizi A, Yang GH, Okitsu K, Zhu JJ. Synthesis of $\mathrm{MnO} 2$ nanoparticles from sonochemical reduction of $\mathrm{MnO} 4$ in water under different $\mathrm{pH}$ conditions. Ultrasonics sonochemistry. 2014;21:1629-1634.

13. Chang YN. Fourier Transform Infrared (FTIR) Analysis of Copper Oxide Thin Films Prepared by Metal Organic Chemical Vapor Deposition (MOCVD). In: MRS Proceedings; 1992. p. 443.

14. Rahman A, Ismail A, Jumbianti D, Magdalena $S$, Sudrajat $H$. Synthesis of copper oxide nano particles by using Phormidium cyanobacterium. Indonesian Journal of Chemistry. 2010;9:355-360.

15. Varughese G, Rini V, Suraj S, Usha K. Characterisation and optical studies of copper oxide nanostructures doped with lanthanum ions. Advances in Materials Science. 2014;14:49-60.

16. Luo J, Zhang Q, Huang A, Suib SL. Microporous Mesoporous Materials; 2002. p. 35-36.

17. Pu ZY, Liu XS, Jia AP, Xie YL, Lu JQ, Luo MF. Enhanced Activity for CO Oxidation over Pr- and Cu-Doped CeO2 Catalysts: Effect of Oxygen Vacancies. The Journal of Physical Chemistry C. 2008;112:15045-15051. 2008/09/25. 


\title{
Nghiên cứu xử lý khí thải chứa CO sử dụng xúc tác tự chế tạo
}

\author{
Nguyễn Thị Bích Thảo, Nguyễn Nhật Huy*
}

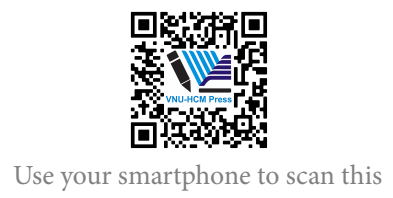

QR code and download this article

\section{TÓM TÁ́T}

Carbon monoxide (CO) là chất gây ô nhiễm không khí độc hại sinh ra từ lò hơi đốt củi vốn được sư dụng rộng rãi trong các doanh nghiệp vừa và nhỏ tại Việt Nam. Việc xử lý khí thải CO đang phải đối mặt với nhiêu khó khăn do tính chất trơ của $\mathrm{CO}$ và không thể được xử lý bằng các phương pháp hấp phụ và hấp thụ truyền thống và một trong những phương phap xử lý CO có hiệu quả là phương pháp oxy hóa có sử dụng xúc tác. Do đó, chúng tôi đã hướng đến việc điều chế các chất xúc tác khác nhau trên các chất mang khác nhau để xử lý $\mathrm{CO}$ trong khí thải, bao gồm $\gamma$ - $\mathrm{Al}_{2} \mathrm{O}_{3}$ $\left(\mathrm{CO}_{3} \mathrm{O}_{4} / \mathrm{Al}_{2} \mathrm{O}_{3}, \mathrm{Cr}_{2} \mathrm{O}_{3} / \mathrm{Al}_{2} \mathrm{O}_{3}\right.$, và $\left.\mathrm{CuO} / \mathrm{Al}_{2} \mathrm{O}_{3}\right), \mathrm{CuO}-\mathrm{MnOx} / \mathrm{OMS}-2$, và $\mathrm{CuO}-\mathrm{MnOx} / z e o l i t$. Quá trình thử nghiệm xử lý $\mathrm{CO}$ được thực hiện trong một thiết bị phản ứng cố định liên tục ở quy mô phòng thí nghiệm với phạm vi nhiệt độ từ $50-550^{\circ} \mathrm{C}$. Các đặc trưng của vật liệu xúc tác được xác định bằng các phương pháp như đo diện tích bề mặt riêng, nhiễu xạ tia X, phổ tán xạ năng lượng tia $X$, phổ dao động hổng ngoại, hiển vi điện tử quét và phân tích nhiệt trọng trường. Kết quả cho thấy CuO-MnOx/OMS-2 là chất xúc tác tốt nhất với hiệu suất xử lý cao đến 98,41\% ở nhiệt độ thiết bị phản ứng là $250^{\circ} \mathrm{C}$ nhưng nhiệt độ khí đầu ra $<50^{\circ} \mathrm{C}$, chứng minh sự phù hợp của vật liệu cho quá trình xử lý $\mathrm{CO}$ trong khí thải. Điều này được giải thích tuân theo cơ chế Mars-Van-Krevelen với sự tồn tại của cặp oxy hóa - khử $\mathrm{Cu}^{2+}-\mathrm{O}^{2-}-\mathrm{Mn}^{4+} \leftrightarrow \mathrm{Cu}^{+}-\square-\mathrm{Mn}^{3+}+\mathrm{O}_{2}$ trong cấu trúc của vật liệu. Bên cạnh đó, ảnh hưởng của các điều kiện vận hành khác như nồng độ $\mathrm{CO}$ đâuu vào, lưu lượng dòng khí thải, và khối lượng xúc tác sử dụng lên hiệu quả xử lý CO cũng được khảo sát để đưa ra những đề xuất hợp lý cho việc thiết kế và vận hành hệ thống xử lý $\mathrm{CO}$ bằng xúc tác. Nồng độ $\mathrm{CO}$ sau quá trình xử lý đạt quy chuẩn QCVN 19: 2009/BTNMT - Quy chuẩn kĩ thuật quốc gia về khí thải công nghiệp đối với bụi và các chất vô cơ. Như vậy, vật liệu xúc tác $\mathrm{CuO}-\mathrm{MnO}_{x} / \mathrm{OMS}-2$ là một chất xúc tác tiêm năng trong việc ứng dụng để xử lý CO trong khí thải lò hơi đốt biomass.

Từ khoá: cácbon monoxít, oxy hóa, xúc tác, kiểm soát ô nhiễm không khí
Trường Đại học Bách Khoa,

ĐHQG-HCM

\section{Liên hệ}

Nguyễn Nhật Huy, Trường Đại học Bách

Khoa, ĐHQG-HCM

Email: nnhuy@hcmut.edu.vn

Lịch sử

- Ngày nhận: 07-3-2019

- Ngày chấp nhận: 14-6-2019

- Ngày đăng: 31-12-2019

DOI : 10.32508/stdjet.v2iSI2.469

\section{Check for updates}

\section{Bản quyền}

(c) ĐHQG Tp.HCM. Đây là bài báo công bố mở được phát hành theo các điều khoản của the Creative Commons Attribution 4.0 International license.

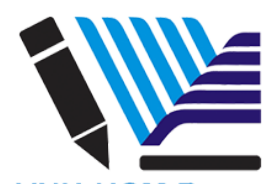

VNU-HCM Press
Trích dẫn bài báo này: Thảo N T B, Huy N N. Nghiên cứu xử lý khí thải chứa CO sử dụng xúc tác tự chế tạo. Sci. Tech. Dev. J. - Eng. Tech.; 2(SI2):SI31-SI39. 